\title{
Efisiensi Penggunaan Citra Multisensor untuk Pemetaan Tutupan Lahan
}

\section{The Efficiency of Multisensor Images for Land Cover Mapping}

\author{
Oleh: \\ Juang Arif Andiko ${ }^{1 *}$, Duryat ${ }^{1}$, Arief Darmawan ${ }^{1}$ \\ ${ }^{1}$ Jurusan Kehutanan, Fakultas Pertanian, Universitas Lampung. Jl. Sumantri Brojonegoro 1, Bandar \\ Lampung, 35145, Lampung, Indonesia \\ *email: juangarifandiko94@gmail.com
}

\begin{abstract}
ABSTRAK
Teknologi penginderaan jauh dan system informasi geografis selalu berkembang dan telah melahirkan berbagai macam citra yang direkam menggunakan multisensor (berbagai jenis citra). Penelitian ini bertujuan untuk membandingkan efektivitas dan efisiensi citra satelit dan SPOT 7, Landsat-8, Sentinel-2 yang digunakan pada peta tutupan lahan Hutan Tahura WAR. Metode yang digunakan adalah metode Analytical Hierarchy Process (AHP) dan perbandingan parameter. Nilai bobot dan skor AHP masing-masing parameter (biaya, proses pengolahan, ketersediaan citra, waktu, dan akurasi) di hasilkan dari wawancara dengan ahli atau praktisi pengguna citra satelit, sedangkan perbandingan parameter dianalisis dengan studi literatur dan perhitungan manual. Hasil penelitian menunjukkan bahwa citra yang paling efektif dan efisien adalah citra Sentinel-2. Citra tersebut tergolong sangat baik ditinjau dari segi biaya, akurasi, proses pengolahan dan resolusi yang dimilikinya.
\end{abstract}

Kata kunci: Analytical Hierarchy Process, citra satelit, sistem informasi geografis, Tahura WAR, tutupan lahan

\begin{abstract}
Remote sensing technology and Geographic Information System are always enhancing and had produced various types of images recorded by multi-sensors. This study research aimed to compare the effectiveness and efficiencyof Landsat-8, Sentinel-2, dan SPOT 7images for land cover mapping atEducational Forest of Great Forest Park Wan Abdul Rahman of Lampung. This study used the Analytical Hierarchy Process (AHP) and parameter comparison as the research methods. The value and AHP scores of each parameter (time, cost, image availability, accuracy and processing time) were obtained through an interview with practitioners and experts, while parameter comparison was analyzed by literature study and quantitative comparison. The results showed that the most effective and efficient image was Sentinel-2 since it gave the best value in terms of cost, accuracy, processing and the resolution of the image.
\end{abstract}

Keywords: Analytical Hierarchy Process, Geographic Information System, land cover, satellite imagery, Tahura WAR 


\section{PENDAHULUAN}

Penginderaan jauh merupakan salah satu teknologi yang telah berkembang pesat. Hal ini dibuktikan dengan semakin banyaknya ragam wahana, sensor dan sistem penginderaan jauh yang ada. Teknologi penginderaan jauh telah menghasilkan berbagai jenis citra yang direkam dengan berbagai sensor (multisensor). Penggunaan teknologi penginderaan jauh atau system informasi geografis dianjurkan karena memiliki kelebihan dalam waktu dan minimnya kesalahan dibandingkan dengan data pengamatan langsung di lapangan (Murti 2012).

Data spasial diperlukan untuk pemantauan sumberdaya hutan dan pemantauan konversi lahan yang tejadi pada kawasan hutan (Sampurno dan Thoriq 2016). Maka sebab itu, teknik pemantauan sumberdaya hutan yang tepat perlu dikembangkan (Pumida 2010). Penginderaan jauh adalah salah satu teknologi yang digunakan untuk teknik pemantauan tutupan lahan dengan jarak jauh yang selanjutnya akan didapat informasi mengenai penutupan vegetasi lahan secara cepat, akurat dan efisien (Syam et al. 2012). Efisiensi dan efektivitas dalam pemetaan tutupan lahan sangat diperlukan untuk mendukung pengelolaan hutan yang baik.

Metode Analytic Hierarchy Process (AHP) merupakan salah satu sistem pendukung pengambilan keputusan. Metode ini memiliki kemampuan analisa yang dapat membantu dalam pemilihan citra. AHP merupakan sistem pengambilan keputusan dengan menggunakan perbandingan berpasangan (Pairwise Comparisons) untuk menjelaskan faktor evaluasi dan faktor bobot dalam kondisi multi faktor. Metode AHP banyak digunakan ketika pengambil keputusan merasa kesulitan dalam membuat bobot setiap faktor atau parameter yang berpengaruh. Konteks penggunaan AHP dalam penelitian ini adalah bagaimana pemilihan citra satelit yang terbaik untuk pemetaan tutupan lahan. Penilaian parameter dilakukan untuk mendukung hasil dari metode AHP, adapun parameter yang digunakan adalah akurasi, biaya, waktu, proses pengolahan citra dan ketersediaan citra (Sutanto 2016).

Penelitian ini bertujuan untuk membandingkan efektivitas dan efisiensi beberapa citra satelit yang biasa digunakan dalam pemetaan tutupan lahan terutama untuk keperluan pengelolaan hutan pendidikan. Citra satelit yang digunakan meliputi citra SPOT 7, Landsat 8 dan Sentinel-2. Citra Landsat 8 memiliki sensor TIRS (Thermal Infrared Sensor) dan OLI (Onboard Operational Land Imager) dengan resolusi 30 m (U.S. Geological Survey 2018). Sentinel-2 Multi-Spectral Instrument (MSI) mempunyai 13 band spektral dengan resolusi 15 $\mathrm{m}$ (European Space Agency 2015). Citra SPOT 7 memiliki keunggulan dibanding citra Landsat 8 dan Sentinel-2 yaitu pada sistem sensornya yang berupa dua sensor identik yang disebut HRVIR (Haute Resolution Visibel Infrared) dan sensor NAOMI (New AstroSat Optical Modular Instrument) dengan resolusi 6 m (Ratermaps 2016).

\section{METODE PENELITIAN}

Penelitian dilakukan pada bulan September 2018 di Universitas Lampung. Bahan yang digunakan pada penelitian ini yaitu Citra Landsat 8 tahun 2017, Citra Sentinel-2 tahun 2018,dan data Citra SPOT7 tahun 2016 yang mencakup Hutan Konservasi Terpadu (HPKT) Taman Hutan Raya Wan Abdul Rahman (Tahura WAR). Alat yang digunakan adalah GPS (Geographic Possitioning System), Garmin 64s, kuesioner, laptop yang dilengkapi dengan aplikasi program software ENVI, ArcGis 10.3, eCognition Developer dan Microsoft office (MS Word, MS Excel), kamera, dan stopwatch. Objek yang digunakan dalam penelitian ini adalah pendapat para ahli (expert) dan praktisi yang berpengalaman dalam pengelolaan data spasial (citra). 
Pengumpulan data untukAnalytic Hierarchy Process (AHP) dilakukan menggunakan kuesioner atau angket. Jumlah responden adalah 3 orang yang terbagi dalam 2 orang ahli dan 1 orang praktisi yang sering menggunakan dan mengolah citra satelit. Sesuai dengan pernyataan Maharani (2017) yang menyatakan bahwa jumlah responden menjadi tidak penting dalam menentukan bobot, namun yang lebih penting adalah kualitas atau pengetahuan responden terhadap permasalahan yang dimaksud. Kuesioner yang digunakan dalam penelitian ini merupakan jenis kuesioner langsung yang bersifat tertutup (responden hanya memberikan tanda pada jawaban yang dianggap benar). Teknik ini digunakan untuk mendapatkan data primer berupa parameter yang paling berpengaruh, yaitu: biaya, waktu, akurasi, ketersediaan citra, proses pengolahan citra dan akurasi.

Metode AHP juga membantu membuat ranking alternative keputusan dan memilih yang terbaik dengan bantuan expert judgement (Ahmad 2018). Expert judgement adalah nilainilai variabel penentu yang dikemukakan para ahli atau praktisi ang memiliki pengalaman cukup lama di bidang pemetaan dan penggunaan citra. Setelah itu dilakukan perhitungan normalisasi dan uji konsistensi. Jika nilai konsistensi di atas 0,1 maka hasil dari wawancara yang telah dilakukan tidak dapat digunakan (Sasongko et al. 2017). Data tersebut kemudian dinormalisasi dan diuji konsistensinya (Santoso et al. 2016) dan diolah menggunakan $M S$ Excel untuk memperoleh bobot masing-masing parameter. Prinsip kerja AHP adalah sebagai berikut:

1. Penyusunan hierarki.

Masalah yang akan diselesaikan diuraikan menjadi unsur-unsur, yaitu: kriteria, sub kriteria dan alternatif; setelah itu disusun menjadi struktur hierarki. Menyusun hirarki, tidak ada aturan yang dapat dilanggar, serta dalam menyusun hierarki bergantung pada keputusan yang perlu diambil (Sasongko et al. 2017).

2. Penilaian kriteria.

Kriteria dapat dilihat dari perbandingan berpasangan untuk beragam jenis persoalan. Skala terbaik dalam mengeskpresikan pendapat dapat dilihat dari skala 1-9. Skala perbandingan nilai dan definisi pendapat kualitatif dari skala perbandingan (Saaty 1993) disajikan pada Tabel 1 .

Tabel 1. Skala penilaian perbandingan(Saaty 1993).

\begin{tabular}{|c|c|c|}
\hline $\begin{array}{l}\text { Skala Tingkat } \\
\text { Kepentingan }\end{array}$ & Definisi & Keterangan \\
\hline 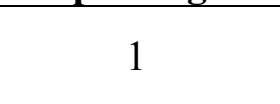 & $\begin{array}{l}\text { Sama } \\
\text { pentingnya }\end{array}$ & Kedua elemen memiliki pengaruh yang sama \\
\hline 3 & $\begin{array}{l}\text { Sedikit lebih } \\
\text { penting }\end{array}$ & $\begin{array}{l}\text { Pengalaman dan penilaian sedikit memihak satu elemen } \\
\text { dibandingkan dengan pasangannya }\end{array}$ \\
\hline 5 & $\begin{array}{l}\text { Lebih } \\
\text { penting }\end{array}$ & $\begin{array}{l}\text { Pengalaman dan penilaian sangat memihak satu elemen } \\
\text { dibandingkan dengan pasangannya }\end{array}$ \\
\hline 7 & $\begin{array}{l}\text { Sangat } \\
\text { penting }\end{array}$ & $\begin{array}{l}\text { Satu elemen sangat disukai dan secara praktis } \\
\text { dominasinya sangat nyata dibandingkan dengan } \\
\text { pasangannya }\end{array}$ \\
\hline 9 & $\begin{array}{l}\text { Mutlak } \\
\text { lebih } \\
\text { penting }\end{array}$ & $\begin{array}{l}\text { Satu elemen terbukti mutlak lebih disukai dibandingkan } \\
\text { dengan pasangannya, pada tingkat keyakinan yang } \\
\text { tertinggi }\end{array}$ \\
\hline $2,4,6,8$ & Nilai tengah & $\begin{array}{l}\text { Diberikan bila terdapat keraguan penilaian antara dua } \\
\text { penilaian yang berdekatan. }\end{array}$ \\
\hline
\end{tabular}




\section{Penentuan Prioritas.}

Kompromi diperlukan antara dua pertimbangan pada setiap kriteria dan alternatif, mestinya dilakukan perbandingan berpasangan. Nilai-nilai yang diperoleh dari perbandingan relatif kemudian diolah untuk menentukan peringkat relatif dari seluruh alternatif. Kriteria kualitatif maupun kriteria kuantitatif, dapat dibandingkan sesuai dengan judgement yang telah ditentukan untuk bobot dan prioritas.

4. Konsistensi Logis.

Unsur-unsur di kelompokkan dan diurutkan secara konsisten sesuai dengan kriteria logis. CR merupakan parameter untuk memeriksa perbandingan berpasangan dilakukan secara konsekuen / tidak. Unsur-unsur yang dikelompokkan harus memiliki nilai $\mathrm{CR}=0,1$ (Arisusanty et al. 2018).

Analisis AHP kemudian didukung dengan analisis komparatif yang mana dilakukan dengan membandingkan ketiga citra yaitu Citra Landsat 8 tahun 2017, Citra Sentinel-2 tahun 2018, dan data Citra SPOT 7 tahun 2016 yang telah diolah sebelumnya. Pengolahan dan studi literatur ketiga citra akan menampakkan kelebihan dan kekurangan citra terhadap parameter biaya, waktu ketersediaan citra, akurasi citra, dan proses pengolahan citra. Biaya merupakan harga yang dikeluarkan untuk mendapatkan citra dengan resolusi rendah murah dibandingkan dengan resolusi tinggi. Waktu pengolahan citra yaitu lama waktu sesorang untuk mengolah suatu citra satelit menjadi peta tutupan lahan dengan menghitung waktu pengolahan menggunakan stopwatch. Ketersediaan citra adalah berapa banyak sebuah perusahaan menghasilkan citra dalam satu waktu. Proses pengolahan juga menjadi parameter penilaian dengan cara menilai bagaimana proses pengolahan citra apakah rumit atau tidak. Akurasi merupakan perbandingan antara data hasil klasifikasi dengan kondisi lapangan. Dalam proses tersebut, perlu dilakukannya pengecekan dan pengambilan sampel dilapangan untuk pembanding. Secara sistematis skema perhitungan akurasi ada 2 yaitu overall accuracy dan kappa accuracy. Hasil penilaian masing-masing parameter akan mendukung nilai yang didapat dari metode AHP.

\section{HASIL DAN PEMBAHASAN}

\section{Bobot Antar Parameter}

Parameter akurasi menunjukkan bahwa akurasi merupakan parameter penting dalam pemilihan citra satelit (Tabel 2). Hasil ini sesuai dengan penelitian Nawangwulan et al. (2013) bahwa akurasi menjadi hal penting dalam pemetaan lahan untuk mengetahui tingkat ketelitian pemetaan pada saat melakukan klasifikasi. Parameter biaya, ketersediaan citra, proses pengolahan, dan waktu pengolahan menjadi hal penting setelah akurasi citra dan harus tetap diperhitungkan dalam pemilihan citra satelit. Hal tersebut sejalan dengan pernyataan Oktaviani dan Johan (2016) menyatakan dalam pemilihan citra satelit ada beberapa hal yang harus dipertimbangkan seperti biaya, proses pengolahan, ketersediaan citra,dan waktu pengolahan citra yang harus disesuaikan dengan kemampuan dan kebutuhan pengguna.

Tabel 2. Penilaian bobot parameter.

\begin{tabular}{lrrrrrr}
\hline Parameter & Waktu & Biaya & $\begin{array}{r}\text { Ketersediaan } \\
\text { citra }\end{array}$ & Akurasi & $\begin{array}{r}\text { Proses } \\
\text { pengolahan }\end{array}$ & Bobot \\
\hline Waktu & 1,00 & 0,30 & 2,00 & 0,50 & 0,30 & 0,12 \\
Biaya & 3,00 & 1,00 & 4,00 & 0,50 & 3,00 & 0,30 \\
Ketersediaan citra & 0,50 & 0,25 & 1,00 & 0,30 & 0,50 & 0,08 \\
Akurasi & 2,00 & 2,00 & 3,00 & 1,00 & 3,00 & 0,35 \\
Proses pengolahan & 2,00 & 0,30 & 2,00 & 0,30 & 1,00 & 0,14 \\
\hline Jumlah & 8,50 & 3,90 & 12,00 & 2,60 & 7,80 & 1,00 \\
\hline
\end{tabular}


Nilai dari Tabel 2 diuji melalui pengukuran konsistensi nilai (nilai CR). Pengukuran nilai CR disajikan pada Tabel 3. Hasil perhitungan CR menunjukkan bahwa data expert judgement tersebut konsisten dalam menilai akurasi sebagai komponen yang berpengaruh besar pada pemilihan citra satelit. Hal tersebut sesuai dengan pernyataan Sasongko et al. (2017) bahwa jika nilai CR di bawah 0,1 maka data expert judgement dapat digunakan karena terbilang konsisten, sebaliknya bila nilai CR lebih dari 0,1 maka hasil dari expert judgement tidak dapat dipakai karena tidak konsisten.Penilaian selanjutnya adalah masing-masing parameter terhadap ketiga citra yang disajikan pada Tabel 4.

Tabel 3.Pengukuran konsistensi nilai (CR).

\begin{tabular}{rrrrrrr}
\hline Bobot & Hasil Kali & HasilKali/Bobot & Lambda & $\mathbf{C i}$ & $\mathbf{R i}$ & $\mathbf{C R}$ \\
\hline 0,11 & 0,51 & 4,83 & 4,27 & $-0,18$ & 1,19 & $-0,15$ \\
0,31 & 2,52 & 8,19 & & & & \\
0,08 & 0,28 & 3,49 & & & & \\
0,36 & 1,02 & 2,81 & & & & \\
0,15 & 0,29 & 2,00 & & & & \\
\hline
\end{tabular}

Penilaian parameter pada citra Sentinel-2, SPOT 7 dan Landsat 8 menghasilkan nilai yang berbeda karena masing-masing citra memiliki kelebihan dan kekurangan terhadap lima parameter.

Tabel 4.Penilaian masing-masing parameter terhadap ketiga citra.

\begin{tabular}{rrrrrr}
\hline Kriteria & Akurasi & Biaya & $\begin{array}{r}\text { Proses } \\
\text { pengolahan }\end{array}$ & Waktu & $\begin{array}{r}\text { Ketersediaan } \\
\text { citra }\end{array}$ \\
\hline Landsat 8 & 0,16 & 0,43 & 0,28 & 0,57 & 0,13 \\
Sentinel-2 & 0,25 & 0,47 & 0,58 & 0,33 & 0,28 \\
SPOT 7 & 0,59 & 0,10 & 0,13 & 0,10 & 0,58 \\
\hline CR & 0,04 & 0,00 & 0,03 & 0,03 & 0,03 \\
\hline
\end{tabular}

\section{Skor Terbobot}

Perhitungan terakhir yang dilakukan untuk pemilihan citra satelit adalah menghitung nilai skor terbobot masing-masing citra yang dijadikan alternatif. Nilai skor terbobot diperoleh dengan cara mengalikan nilai bobot setiap parameter dengan nilai parameter pada masing-masing citra (Rais 2016). Tabel 5 menunjukkan bahwa Sentinel-2 lebih dianjurkan untuk pemetaan tutupan lahan karena memiliki skor terbobot $>$ citra SPOT 7 dan citra Landsat 8. Hal ini sesuai dengan pernyataan Wahyuningsih (2014)bahwa keputusan terakhir dalam pemilihan citra satelit dengan menggunakan metode AHP adalah melihat skor terbobot yang paling besar nilainya.

Tabel 5. Bobot prioritas parameter penilaian.

\begin{tabular}{clrrr}
\hline Citra & Parameter & Bobot & Skor & $\begin{array}{r}\text { Skor } \\
\text { Terbobot }\end{array}$ \\
\hline Landsat 8 & a. akurasi & 35 & 0,16 & \\
& b. biaya & 30 & 0,43 & \\
& c. proses pengolahan & 14 & 0,28 & 0,30 \\
& d. waktu & 12 & 0,57 & \\
& e. ketersediaan citra & 8 & 0,13 & \\
\hline Sentinel-2 & a. akurasi & 35 & 0,25 & \\
& b. biaya & 30 & 0,47 & \\
& c. proses pengolahan & 14 & 0,58 & 0,38 \\
\hline
\end{tabular}




\begin{tabular}{llrrr}
\hline Citra & Parameter & Bobot & Skor & $\begin{array}{r}\text { Skor } \\
\text { Terbobot }\end{array}$ \\
\hline \multirow{2}{*}{ Spot 7} & d. waktu & 12 & 0,33 & \\
& e. ketersediaan citra & 8 & 0,28 & \\
& a. akurasi & 35 & 0,59 & \\
& b. biaya & 30 & 0,10 & \multirow{2}{*}{0,32} \\
& c. proses pengolahan & 14 & 0,13 & \\
& d. waktu & 12 & 0,10 & \\
& e. ketersediaan citra & 8 & 0,58 & \\
\hline
\end{tabular}

\section{Penilaian parameter}

Citra Sentinel-2 paling efektif dan efisien digunakan ditinjau dari segi biaya, akurasi, proses pengolahan dan resolusi yang dimiliki citra ini tergolong sangat baik (Tabel 6); selain didukung dengan nilai skor terbobot dari metode AHP $>$ citra SPOT 7 dan Landsat 8. Citra yang dibandingkan memiliki keunggulan dan kekurangan masing-masing.

Tabel 6. Hasil parameter penilaian.

\begin{tabular}{lccc}
\hline \multirow{2}{*}{ Parameter Penilaian } & \multicolumn{3}{c}{ Citra } \\
\cline { 2 - 4 } & Landsat 8 & Sentinel-2 & SPOT 7 \\
\hline Waktu & $39,42 \mathrm{~m}$ & $48,22 \mathrm{~m}$ & $99,07 \mathrm{~m}$ \\
Biaya & Rp. 0 & Rp. 0 & Rp. 0* atau Rp. \pm \\
& & & 1,7 juta \\
Ketersediaan citra & 16 hari & 5 hari & $1-3$ hari \\
Akurasi & $87 \%$ & $89 \%$ & $94 \%$ \\
Proses pengolahan & Mudah & Mudah & Sulit \\
\hline
\end{tabular}

Keterangan: * jika ada rekomendasi dari instansi tertentu.

Waktu pengolahan citra Sentinel-2 sedikit lebih lama dari Landsat 8 tetapi lebih cepat dibandingkan SPOT 7. Resolusi pada citra Landsat 8 dan Sentinel-2 termasuk menengah karena memiliki resolusi $30 \mathrm{~m}$ dan $15 \mathrm{~m}$, sedangkan SPOT 7 merupakan citra yang memiliki resolusi tinggi yaitu $6 \mathrm{~m}$. Hal ini sesuai dengan pengelompokkan resolusi spasial (Yanuar et al. 2018) sebagai berikut: 30m - $1.000 \mathrm{~m}$ (resolusi rendah), 5 - $30 \mathrm{~m}$ (resolusi menengah), dan 0,4 - $5 \mathrm{~m}$ (resolusi tinggi). Menurut Oktaviani dan Johan (2016) waktu pengolahan citra Sentinel-2 hampir sama dengan citra Landsat 8 karena keduanya tidak memakan waktu lama, tetapi untuk citra SPOT 7 cukup lama karena memiliki resolusi tinggi sehingga membutuhkan ruang data yang lebih besar

Biaya Sentinel-2 sama dengan Landsat 8 karena keduanya bisa didapatkan secara gratis, berbeda dengan SPOT 7 yang membutuhkan biaya yang cukup mahal untuk mendapatkannya. Hal ini sesuai dengan pernyataan Apollo Mapping (2019) bahwa citra SPOT 7 memiliki harga yang cukup mahal jika tidak ada rujukan/rekomendasi dari instansi tertentu. Citra SPOT 7 memiliki harga USD 5,75 per $\mathrm{km}^{2}$ untuk multispektral dan USD 4,15 untuk pankromatik dengan minimal pembelian citra $500 \mathrm{~km}^{2}$.

Ketersediaan citra atau resolusi temporal cukup bervariasi antara ketiga citra, dimana resolusi temporal SPOT 7 tinggi, citra Landsat 8 rendah, dan Sentinel-2 sedang. Hal ini sesuai dengan pernyataan Suwargana (2013) bahwa kisaran resolusi temporal tinggi adalah $<24$ jam - 3 hari, resolusi temporal sedang antara 4-16 hari, dan resolusi temporal rendah> 16 hari. Ketersediaan citra atau resolusi temporal yang terbilang sedang menjadikan citra Sentinel-2 lebih unggul karena pemetaan tutupan lahan hutan harus dilakukan secara berkelanjutan untuk mendukung dalam mengolah hutan yang lebih baik. 
Akurasi hasil klasifikasi citra penelitian ini dapat diterima karena memiliki nilai $87 \%$, $89 \%$ dan 94\%. Menurut Howard (1996), nilai akurasi $>85 \%$ menunjukkan bahwa hasil klasifikasi benar atau dapat diterima dengan tingkat kesalahan $\leq 15 \%$, sehingga hasil akurasi yang didapat sudah layak untuk digunakan dan tidak perlu dilakukan klasifikasi ulang. Klasifikasi harus diulang jika nilai dari overall accuracy besarnya kurang dari $85 \%$. Semakin tinggi akurasinya, baik overall accuracy maupun kappa agreement, maka hasil klasifikasi yang diperoleh akan semakin baik (Sudarsono et al. 2018). Hal tersebut sesuai dengan yang dikemukakan oleh Astriani et al. (2017) bahwa citra Sentinel-2 memiliki resolusi sedang, sehingga menghasilkan nilaiakurasi yang baik. Perhitungan akurasi yang didapat yaitu $89 \%$, nilai tersebut di atas standar nilai akurasi yang telah ditetapkan.

Proses pengolahan pada ketiga citra secara umum sama, tetapi pada citra SPOT 7 dilakukan perlakuan pan-sharpening (penajaman citra) sehingga lebih sulit dibandingkan pengolahan citra Landsat 8 dan Sentinel-2. Proses pengolahan juga berhubungan dengan lama waktu yang dibutuhkan dalam mengolah citra. Proses pengolahan yang mudah dan tidak memakan waktu yang lama membuat citra Sentinel-2 lebih unggul dibandingkan citra SPOT 7 dan Landsat 8.

\section{SIMPULAN}

Tingkat efisiensi dan efektifitas citra Sentinel-2 merupakan citra yang lebih efektif dan efisien untuk digunakan dibandingkan citra satelit Landsat-8 dan SPOT 7. Citra tersebut lebih unggul karena hemat biaya, ketersediaan citra yang cukup cepat, akurasi yang cukup tinggi, pengolahan citra yang tidak memakan waktu lama, serta proses pengolahan yang cukup mudah.

\section{DAFTAR PUSTAKA}

Apollo Mapping. 2019. Apollo Mapping Price List: Medium \& High-Resolution Satellite + Aerial Imagery. Boulder, Colorado.

Arisusanty, D. J., Arkeman, Y., Rahardjo, S., and Soeboer, D. A. 2018. Analisa Menentukan Kriteria Pemilihan Pelabuhan Pengumpan Tol Laut menggunakan Metode AHP. ALBACORE 2(1): 57-67.

Astriani, H., Santoso, K. B., Arifatha, N., Prasetya, R., Utomo, S. D., Juniandari, V. C., and Kamal, M. 2017. Perbandingan Citra Landsat 8 OLI dan Sentinel 2-A untuk Estimasi Stok Karbon Kelapa Sawit (Elais Guineensis Jacq) di Wilayah PT. Perkebunan Nusantara VII Unit Rejosari, Natar, Kabupaten Lampung Selatan. in: Seminar Nasional Geomatika 2017: Inovasi Teknologi Penyediaan Informasi Geospasial untuk Pembangunan Berkelanjutan 21-28.

European Space Agency. 2015. SENTINEL-2 User Handbook. European Space Agency (ESA).

Handoko, ., and Darmawan, A. 2015. Perubahan Tutupan Hutan di Taman Hutan Raya Wan Abdul Rachman (Tahura War). Jurnal Sylva Lestari 3(2): 43-52. DOI: $10.23960 /$ js $12343-52$

Hasdinata, H. R. 2015. Analisis Tutupan Lahan Menggunakan citra Landsat di Hutan Pendidikan Gunung Walat. Institut Pertanian Bogor.

Howard, J. A. 1996. Penginderaan Jauh untuk Sumber Daya Hutan: Teori dan Aplikasi. Gadjah Mada University Press, Yogyakarta.

Maharani, D. 2017. Pemilihan Strategi Kebijakan Transportasi di Bandar Lampung dengan 
Menggunakan Metode Analytical Hierarchy Process. Universitas Lampung.

Murti, S. H. 2012. Pengaruh Resolusi Spasial pada Citra Penginderajaan Jauh terhadap Ketelitian Pemetaan Penggunaan Lahan Pertanian di Kabupaten Wonosobo. Jurnal Ilmiah Geomatika 18(1): 84-94.

Nawangwulan, N. H., Sudarsono, B., and Sasmito, B. 2013. Analisis Pengaruh Perubahan Lahan Pertanian terhadap Hasil Produksi Tanaman Pangan di Kabupaten Pati Tahun 2001 - 2011. Jurnal Geodesi Undip 2(2): 127-140.

Oktaviani, A., and Johan, Y. 2016. Perbandingan Resolusi Spasial, Temporal dan Radiometrik serta Kendalanya. Jurnal Enggano 1(2): 74-79. DOI: 10.31186/jenggano.1.2.74-79

Pumida. 2010. Identifikasi Tutupan Lahan dengan Citra Alos Palsar Resolusi $50 \mathrm{~m}$ dan 12,5 m (Studi Kasus di Propinsi D.I. Yogyakarta dan Jawa Tengah). Institut Pertanian Bogor.

Rais, M. S. 2016. Sistem Pendukung Keputusan untuk Pemilihan Lokasi Perumahan Menggunakan Analytical Hierarchy Process (AHP). Riau Journal Of Computer Science 2(2): 59-72.

Ramanda Putri, D., Sukmono, A., and Sudarsono, B. 2018. Analisis Kombinasi Citra Sentinel-1a dan Citra Sentinel-2a untuk Klasifikasi Tutupan Lahan (Studi Kasus: Kabupaten Demak, Jawa Tengah). Jurnal Geodesi Undip 7(2): 85-96.

Ratermaps. 2016. SPOT Satelite Imagery.

Ridlan, A. 2018. Penggunaan SistemPendukung Keputusan dengan Menggunakan Metode Analytical Hirarchy Process (AHP) dalam Menyeleksi Kelayakan Penerima Beasiswa. METIK Jurnal 2(1): 28-33.

Saaty, T. L. 1993. How to Make a Decision: The Analytic Hierarchy Process. European Journal of Operational Research 48(1): 9-26. DOI: 10.1016/0377-2217(90)90057-I

Sampurno, R. M., and Thoriq, A. 2016. Klasifikasi Tutupan Lahan Menggunakan Citra Landsat 8 Operational Land Imager (OLI) Di Kabupaten Sumedang. Jurnal Teknotan 10(2): 61-70. DOI: 10.24198/jt.vol10n2.9

Santoso, A., Rahmawati, R., and Sudarno, S. 2016. Aplikasi Fuzzy Analytical Hierarchy Process untuk Menentukan Prioritas Pelanggan Berkunjung ke Galeri (Studi Kasus di Secondhand Semarang). Jurnal Gaussian 5(2): 239-248.

Sasongko, A., Astuti, I. F., and Maharani, S. 2017. Pemilihan Karyawan Baru dengan Metode AHP (Analytic Hierarchy Process). Jurnal Ilmiah Ilmu Komputer 12(2): 88-93. DOI: 10.30872/jim.v12i2.650

Sutanto. 2016. Metode Penelitian Penginderaan Jauh. Ombak, Yogyakarta.

Suwargana, N. 2013. Resolusi Spasial, Temporal dan Spektral pada Citra Satelit LANDSAT, SPOT dan IKONOS. Jurnal Ilmiah WIDYA 1(2): 167-174.

Syam, T., Darmawan, A., Banuwa, I. S., and Ningsih, K. 2012. Pemanfaatan Citra Satelit dalam Mengidentifikasi Perubahan Penutupan Lahan: Studi Kasus Hutan Lindung Register 22 Way Waya Lampung Tengah. Majalah Ilmiah Globe 14(2): 146-156.

U.S. Geological Survey. 2018. Landsat 8 Data User Handbook. EROS Sious Falls, South Dakota.

UPTD Tahura WAR. 2017. Blok Pengelolaan Taman Hutan Raya Wan Abdul Rachman. UPTD Tahura WAR, Bandar Lampung.

Wahyuningsih, S. 2014. Sistem Pendukung Keputusan untuk Penilaian Kinerja Pegawai Menggunakan Metode Analytical Hierarchy Process (AHP) pada RSUD Serang. Jurnal Sistem Informasi 1(1).

Yanuar, R. C., Hanintyo, R., and Muzaki, A. A. 2018. Penentuan Jenis Citra Satelit dalam Interpretasi Luasan Ekosistem Lamun Menggunakan Pengolahan Algoritma Cahaya Tampak. Jurnal Ilmiah Geomatika 23(2): 75. DOI: 10.24895/jig.2017.23-2.704 